\title{
Nitrogen mineralization and vegetation along skidding tracks
}

\author{
Luise EBRECHT*, Wolfgang SCHMIDT \\ Georg-August-University of Göttingen, Institute of Silviculture and Forest Ecology I, Büsgenweg 1, 37077 Göttingen, Germany
}

(Received 24 June 2002; accepted 2 June 2003)

\begin{abstract}
Forest management requires a dense forest road system which combines truck roads and skidding tracks. However, harvesting machines cause damage to forest stands and soils. The aim of this study is to examine the consequences skidding tracks have on net nitrogen mineralization and vegetation composition compared to adjacent forest stands. A beech forest on limestone as well as beech and Norway spruce forests on acidic soils were investigated in south Lower Saxony, Germany. Along the wheel tracks the net nitrogen mineralization is markedly reduced compared to the undisturbed stands. Although nitrogen mineralization is found to be low especially along the wheel tracks, ruderal plants with high nitrogen indicator values have established themselves. Along the skidding tracks, numerous species from fringe and ruderal communities, grasslands and wet sites occur while the stands are dominated by typical forest plant species. Therefore, species diversity is higher along the skidding tracks than in the adjacent stands.
\end{abstract}

skidding track / beech forest / spruce forest / species diversity / nitrogen mineralization / indicator values

Résumé - Minéralisation d'azote et végétation le long de lignes de débardage. Une gestion forestière durable nécessite un système de desserte forestière dense par des chemins et des lignes de débardage. La circulation d'engins forestiers lourds cause des dégâts parfois importants au sol et aux peuplements forestiers. Une hêtraie calcicole ainsi qu'une hêtraie et une pessière sur des stations acidiclines ont fait l'objet de la présente étude dont l'objectif est l'appréciation des conséquences de la circulation sur la minéralisation d'azote ainsi que sur la végétation. Par rapport à des peuplements voisins non perturbés, la minéralisation d'azote nette dans les ornières est sensiblement ralentie. Malgré ce fait, de nombreuses espèces des ourlets et des milieux ouverts ("espèces rudérales"), présentant un besoin élevé d'azote, apparaissent le long des lignes de débardage. Les peuplements fermés sont caractérisés par des espèces forestières typiques. Ainsi, on constate une plus grande diversité d'espèces le long des lignes de débardage.

ligne de débardage / hêtraie / pessière / diversité d'espèces / minéralisation d'azote / valeurs indicatrices selon Ellenberg

\section{INTRODUCTION}

In many situations forest soils are compacted $[34,61]$ and the ground vegetation is disturbed or even destroyed as a result of travelling and skidding action of harvesting machinery [60, 47]. This is especially obvious along permanent skidding tracks. These are primitive roads without an artificial surface, running through the forests $15-60 \mathrm{~m}$ apart from each other [17]. In the last few years logging with harvesters and skidders has increased because it seemed more economic, more comfortable and safer for workers [6, 13, 33]. Most German forests are subdivided by dense forest road and track systems $[5,17$, 25], of which the consequences are harvesting damage to stand and soil as well as area loss for timber production [3, 17, 62]. However, ecological aspects of skidding tracks on herb layer vegetation have hardly been considered $[11,12,30]$. Also net nitrogen mineralization which is an important factor in ecosystem functions [19] might be influenced along skidding tracks. Nitrogen mineralization allows the estimation of nitrogen sup- ply to plants and is an indicator of biological activity in the soil $[19,56]$. Therefore the aims of this study are to prove the following hypotheses:

1. Along skidding tracks soil compaction leads to a reduction of net nitrogen mineralization.

2. Plant species richness is higher along skidding tracks than in the undisturbed forest stands nearby.

3. Plant species composition changes along skidding tracks in comparison to the undisturbed adjacent stands.

Soil compaction due to heavy machinery strongly depends on the soil type $[7,36]$. In addition, tree species composition influences ecosystem functions, such as nitrogen mineralization, soil characteristics, transmission of light $[4,20,41]$ as well as ground vegetation $[31,58,68]$. Hence, harvesting traffic may lead to different effects depending on the tree species composition, nutrition as well as the naturalness of the vegetation $[8,9,20,55]$. Therefore the investigations took place at two different sites and on three vegetation types. A species

* Corresponding author: lebrech@gwdg.de 


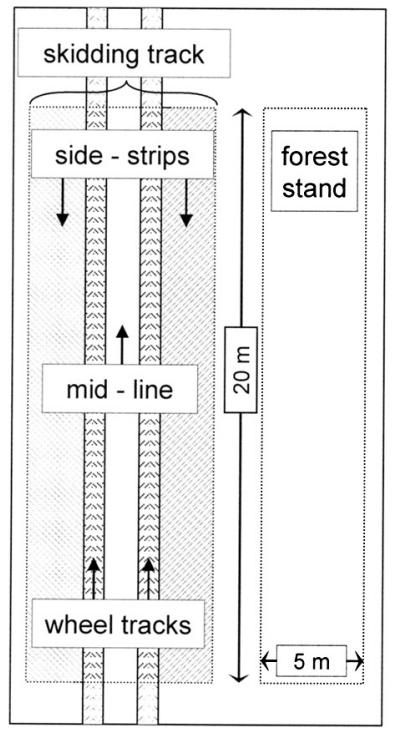

Figure 1. The four experimental plots have been created as illustrated. Skidding tracks consist of side-strips, wheel tracks and mid-line. The undisturbed forest stand is separated from the skidding track by a distance of $5 \mathrm{~m}$.

rich beech (Fagus sylvatica) forest on limestone is compared with a species poor beech (Fagus sylvatica) forest on acidic sandstone. On the sandstone site, the close-to-nature beech forest is also compared with an artificial Norway spruce (Picea abies) forest.

\section{STUDY AREA AND METHODS}

\subsection{Study area}

The research areas are in the Solling uplands and in the Göttingen forest, located in the south of Lower-Saxony, Germany. Both sites are characterised by a subatlantic climate with a moderate altitude between 300-400 $\mathrm{m}$ above sea-level. In the Göttingen forest mean annual temperature is about $8.5^{\circ} \mathrm{C}$ [64]. The annual rainfall is $680 \mathrm{~mm}$, of this $340 \mathrm{~mm}$ falls during the vegetation period (MaySeptember). In the Solling uplands the climate is cooler and moister (mean annual temperature: $7.5^{\circ} \mathrm{C}$, annual rainfall: $900 \mathrm{~mm}$, of which $420 \mathrm{~mm}$ falls during the vegetation period) [38, 46]. The shelly limestone in the Göttingen forest weathered to shallow rendzina soils of the carbonate buffer system while the Solling uplands, a sandstone region covered with a loess overlay, are characterised by acid brown earths of the aluminium buffer system. According to amelioration liming, increased $\mathrm{pH}$ values are recorded in the Solling beech forest. Three vegetation types of mature stands were selected where logging had taken place one year previous to the start of the investigations. In the Göttingen forest, a beech forest on limestone belonging to the Hordelymo-Fagetum [15] was examined while in the Solling uplands the beech forest belongs to the Luzulo-Fagetum [28, 65, 67]. Both beech forests correspond to the potential natural vegetation [40, 63]. However, throughout history the woods had been used intensively. In the Solling the beech forests were often replaced by planting of Norway spruce, which is today distributed over a wide area $[23,28,46$, 67]. This third stand type of examination belongs to the semi-natural Galio harcynici-Culto-Piceetum [65, 67].
Table I. Number of plots $(n)$ and average plot size $\left(\varnothing\right.$ size $\left.\left[\mathrm{m}^{2}\right]\right)$ for all transect units: these are forest stand, side-strips, wheel tracks and midline. In the Göttingen forest a beech forest on limestone, and in the Solling uplands beech and spruce forests on acidic soils were investigated.

\begin{tabular}{|c|c|c|c|c|c|c|c|c|}
\hline & \multicolumn{2}{|r|}{ Stand } & \multicolumn{2}{|c|}{ Side-strips } & \multicolumn{2}{|c|}{ Wheel tracks } & \multicolumn{2}{|c|}{ Mid-line } \\
\hline & $n$ & $\begin{array}{c}\varnothing \text { size } \\
{\left[\mathrm{m}^{2}\right]}\end{array}$ & $n$ & $\begin{array}{c}\varnothing \text { size } \\
{\left[\mathrm{m}^{2}\right]}\end{array}$ & $n$ & $\begin{array}{c}\varnothing \text { size } \\
{\left[\mathrm{m}^{2}\right]}\end{array}$ & $n$ & $\begin{array}{c}\varnothing \text { size } \\
{\left[\mathrm{m}^{2}\right]}\end{array}$ \\
\hline \multicolumn{9}{|l|}{ Göttingen, } \\
\hline beech forest & 15 & 100 & 15 & 42.4 & 12 & 23.6 & 12 & 19.8 \\
\hline \multicolumn{9}{|l|}{ Solling, } \\
\hline beech forest & 14 & 100 & 26 & 41.1 & 9 & 30.4 & 9 & 19.3 \\
\hline spruce forest & 9 & 100 & 18 & 36.1 & 10 & 33.0 & 10 & 28.2 \\
\hline
\end{tabular}

\subsection{Methods}

The nitrogen mineralization, bulk density and the vegetation composition were measured along the skidding tracks in comparison to the nearby undisturbed stands. Data was collected from $20 \mathrm{~m}$ long transects parallel to the skidding tracks. The skidding track was divided into three sections of different disturbance intensities (Fig. 1). The wheel tracks with heavily compacted soils are mainly influenced by the harvesting machines. The mid-line is the area between the wheel tracks where the disturbance intensity is lower. The side-strips extend up to the first line of trees, looking very similar to the closed forest as they are barely effected by the machines. As a reference site the undisturbed adjacent stands were recorded. In the stands a constant size of $100 \mathrm{~m}^{2}$ per plot was chosen, whereas the plot size along the skidding tracks differed depending of their width (Tab. I).

Forest soils are rich in organic nitrogen (up to $9 \mathrm{t} \mathrm{N} \mathrm{ha}^{-1}$ ) [47], however, plants assimilate nitrogen only in its inorganic forms, ammonium and nitrate [19]. Therefore net nitrogen mineralization of the soil was investigated along the wheel tracks and the adjacent stands with an incubation method lasting from March to November 2001 (30 weeks) [43, 69]. Soil samples (two samples per plot) were taken with a soil scorer (diameter $8 \mathrm{~cm}$ ) to avoid soil disturbance [27, $43,44]$. For an incubation period of six weeks these samples were buried at their original place in polyethylene bags to avoid plant assimilation and leaching [22]. In the laboratory the soil monoliths were separated into three layers: the humus layer and the mineral soil at a depth of $0-10 \mathrm{~cm}$ and $10-20 \mathrm{~cm}$. The material was sieved through a $4 \mathrm{~mm}$ sieve. Ammonium and nitrate were determined by a distillation method described by Gerlach [27] and Mrotzek [44]. The difference between the initial concentration of mineral nitrogen and after incubation indicates the mineralization rate within six weeks [43]. As nitrogen mineralization fluctuates seasonally $[43,66]$ the summed mineral nitrogen $\left(\mathrm{N}_{\min }\right)$ values $\left[\mathrm{kg} \mathrm{N}_{\min }\right.$ ha $^{-1} 30$ weeks ${ }^{-1}$, up to $20 \mathrm{~cm}$ soil depth and $\mathrm{ppm} \mathrm{N}_{\text {min }}$ respectively] are presented here.

In order to calculate the values in $\mathrm{kg} \mathrm{N}_{\text {min }}$, the weight of fine soil per unit area $\left[\mathrm{tha}^{-1}\right]$ has been measured in the humus layer and the mineral soil as well as bulk density, which is an important parameter of soil compaction. Nitrification rate is expressed by the rate of nitrate at the total amount of nitrogen mineralization [10]. Two transects for each of the three stand types were investigated. Hence, an arithmetic mean will be given, but it is not possible to calculate differences between them.

Vegetation relevés were recorded on a larger data basis (Tab. I). All vascular plants and mosses were identified working through tree, shrub, herb and moss layer. Plant cover was estimated in percent. Plot 
Göttingen, beech forest Solling, beech forest

Solling, spruce forest

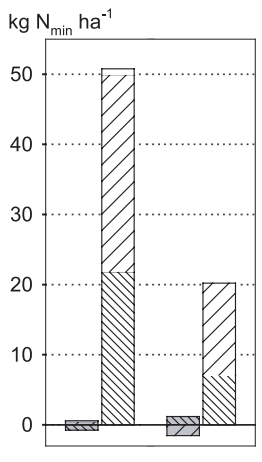

stand wheel tracks $\mathrm{kg} \mathrm{N}_{\min } \mathrm{ha}^{-1}$

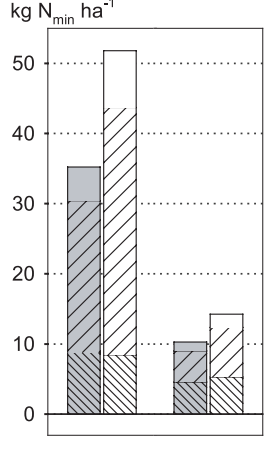

stand wheel tracks

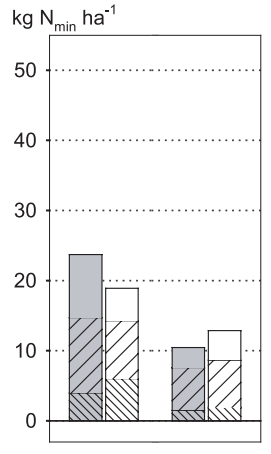

stand wheel tracks

Figure 2. Net mineralization of ammonium and nitrate $\left[\mathrm{kg} \mathrm{N}_{\min } \mathrm{ha}^{-1}\right]$, measured from March to November (30 weeks) in the humus layer and the mineral soil for a depth of $20 \mathrm{~cm}$. The diagrams show the means of two samples from the forest stands and the wheel tracks of the Göttingen beech forest and Solling uplands (beech and spruce forests). For total amounts of nitrogen mineralization see Table II.

size differs between the relevés, but the minimum area for the different vegetation types was used sufficiently [16].

The mean and total number of herb layer species was calculated for the different transect units shown in Table I. The indicator values formed by Ellenberg et al. [21] permit quick estimates of the ecological site conditions for vegetation relevés. The arithmetic mean of indicator values for light, soil reaction and nitrogen were calculated for the herb layer species in the different transect units (Tab. I). The phytosociological behaviour following the grouping introduced by Ellenberg et al. [21] was calculated for all plant species occurring in one transect unit.

\section{RESULTS}

\subsection{Nitrogen mineralization and soil compaction}

The net nitrogen mineralization is higher in the forest stands than along the wheel tracks which only have a low rate of mineralization (Fig. 2). In many cases the soil in the wheel tracks is compacted compared to the soil which was observed in the undisturbed stands (Tab. II), especially in the upper mineral soil in $0-10 \mathrm{~cm}$ depth. The humus rich clay on limestone in the Göttingen forest has a lower bulk density than the sandy soils found in the Solling uplands. In the spruce forest, soil compaction along wheel tracks is rather low, perhaps because of the thick humus layer and the high stone content in $10-20 \mathrm{~cm}$ depth (Tab. II) which partly prevent the soil from soil compaction.

In the Göttingen forest on alkaline soil, the nitrification rate is around $100 \%$ (Fig. 2). The nitrogen supply in the stands (Hordelymo-Fagetum) is relatively low with $51 \mathrm{~kg} \mathrm{~N} \mathrm{ha}^{-1}$, however the wheel tracks have still a markedly smaller mineralization rate (Tab. II). In the forest stand the humus layer on

Table II. Data of soil and nitrogen mineralization of the litter layer and the mineral soil in depths of $0-10 \mathrm{~cm}$ and $10-20 \mathrm{~cm} . n=$ number of samples, given for the forest stands and the wheel tracks on the three study sites. $\pm \mathrm{s}=$ standard deviation.

\begin{tabular}{|c|c|c|c|c|c|c|}
\hline & \multicolumn{2}{|c|}{$\begin{array}{l}\text { Göttingen, } \\
\text { beech forest }\end{array}$} & \multicolumn{2}{|c|}{$\begin{array}{c}\text { Solling, } \\
\text { beech forest }\end{array}$} & \multicolumn{2}{|c|}{$\begin{array}{c}\text { Solling, } \\
\text { spruce forest }\end{array}$} \\
\hline & $\operatorname{stan}$ & eel tracks & stand & wheel tracks & stand & eel tracks \\
\hline$n$ & 8 & 10 & 10 & 10 & 10 & 10 \\
\hline
\end{tabular}

Weight per unit area (fine earth fraction) $\left[\mathrm{t} \mathrm{ha}^{-1}\right]$

\begin{tabular}{lcccccc}
\hline Litter & 4.2 & - & 33.7 & 60.6 & 60.9 & 60.3 \\
$0-10 \mathrm{~cm}$ & 516.1 & 624.1 & 1055.9 & 1212.5 & 801.4 & 734.8 \\
$10-20 \mathrm{~cm}$ & 566.7 & 486.7 & 1067.2 & 1137.8 & 584.9 & 698.4 \\
\hline
\end{tabular}

Bulk density (fine earth fraction) $\left[\mathrm{g} \mathrm{cm}^{-3}\right]$

\begin{tabular}{lllllll}
\hline Litter & 0.09 & - & 0.14 & 0.26 & 0.11 & 0.15 \\
$0-10 \mathrm{~cm}$ & 0.55 & 0.67 & 1.10 & 1.29 & 0.90 & 0.87 \\
$10-20 \mathrm{~cm}$ & 0.61 & 0.59 & 1.12 & 1.19 & 0.78 & 0.90 \\
\hline Stone content [\%] & & & & & \\
\hline $0-10 \mathrm{~cm}$ & 13.8 & 23.4 & 3.9 & 5.9 & 11.0 & 15.0 \\
$10-20 \mathrm{~cm}$ & 8.3 & 21.7 & 4.7 & 4.8 & 26.6 & 22.3 \\
\hline
\end{tabular}

Thickness of the humus layer [cm]

\begin{tabular}{lllllll}
\hline Mean & 0.7 & - & 2.5 & 2.5 & 5.7 & 4.4 \\
$\pm \mathrm{s}$ & 0.6 & - & 1.0 & 1.1 & 1.6 & 1.8 \\
\hline
\end{tabular}

Nitrogen mineralization $\left[\mathrm{ppm} \mathrm{N}_{\min } 30\right.$ weeks $\left.^{-1}\right] ; n=2$

\begin{tabular}{lcccccc}
\hline Litter & 233.4 & - & 381.8 & 51.7 & 223.7 & 117.5 \\
$0-10 \mathrm{~cm}$ & 55.3 & 17.7 & 53.8 & 9.5 & 23.7 & 17.5 \\
$10-20 \mathrm{~cm}$ & 37.2 & 17.0 & 16.2 & 8.7 & 17.1 & 5.0 \\
Total & 325.9 & 34.7 & 451.8 & 69.9 & 264.5 & 140.0
\end{tabular}

Nitrogen mineralization $\left[\mathrm{kg} \mathrm{N}_{\min } \mathrm{ha}^{-1} 30\right.$ weeks $\left.^{-1}\right] ; n=2$

\begin{tabular}{lllllll}
\hline Total & 50.6 & 19.9 & 87.0 & 24.5 & 42.6 & 23.3 \\
\hline
\end{tabular}

the nutrient rich soils is very productive in nitrogen mineralization but thin and is missing along the wheel tracks (Tab. II). As a result the nitrogen mineralization is most effective in biologically very active mineral soil (Fig. 2).

In the beech forest of the Solling site the nitrification rate is near $60 \%$. The nitrogen mineralization in the stand is the highest measured during this study, a total of $87 \mathrm{~kg} \mathrm{~N} \mathrm{ha}^{-1}$. The mineralization rates of the humus layer and the upper mineral soil are very high (Tab. II and Fig. 2). They become lower in the mineral soil between 10 and $20 \mathrm{~cm}$ depth. In contrast along the wheel tracks the mineralization rate is much lower, a total of just $25 \mathrm{~kg} \mathrm{~N} \mathrm{ha}^{-1}$ which means only $28 \%$ of the nitrogen mineralization [ $\mathrm{kg} \mathrm{N}_{\min } \mathrm{ha}^{-1} * 30$ weeks ${ }^{-1}$ ] measured in the stands and $16 \%$ of the nitrogen mineralization [ppm $\mathrm{N}_{\text {min }}$ 30 weeks $^{-1}$ ] respectivley. This difference in percentage is 


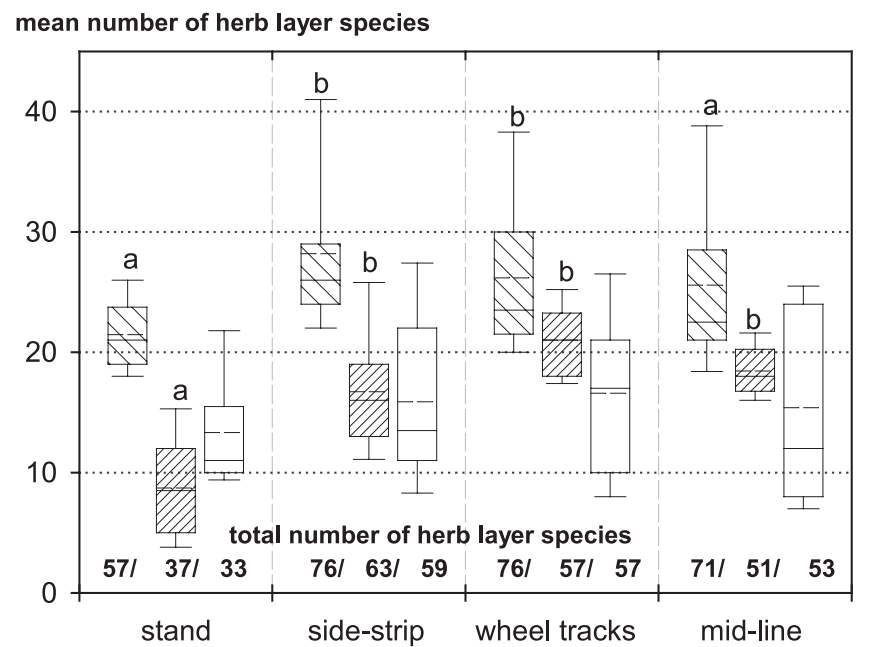

\begin{tabular}{|l|}
\hline Göttingen, beech forest \\
SIIII/ Solling, beech forest \\
\hline Solling, spruce forest
\end{tabular}

solide line: median dashed line: mean value box and whiskers: $10^{\text {th }}, 25^{\text {th }}, 75^{\text {th }}, 90^{\text {th }}$ percentile

Figure 3. Mean and total numbers of herb layer species in the stands, side-strips, wheel tracks and mid-lines of the Göttingen beech forest and Solling uplands (beech and spruce forests). Significant differences within one forest type are differentiated by use of small letters. They were calculated with u-Test (Mann-Whitney), $p>0.05$. $n$ see Table I.

caused by the higher soil bulk density along the wheel tracks which compensate the lower nitrogen mineralization rates $\left[\mathrm{ppm} \mathrm{N}_{\min } 30\right.$ weeks $^{-1}$.
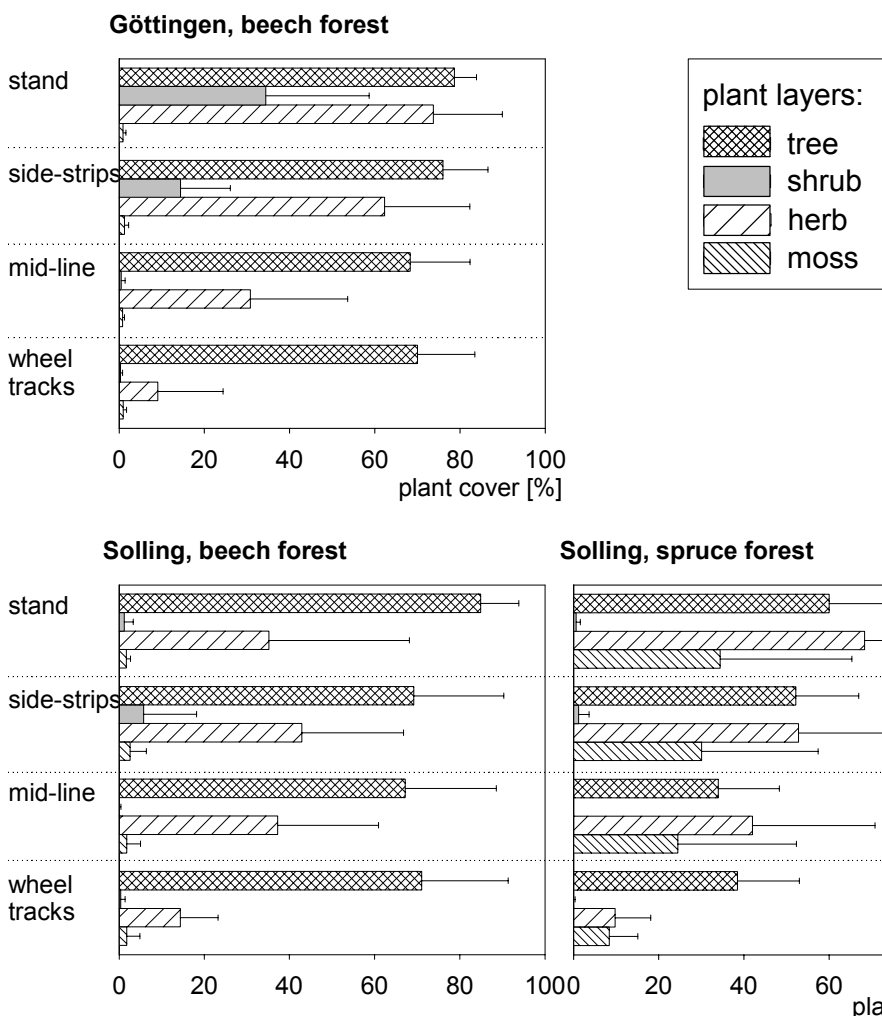

Solling, spruce forest

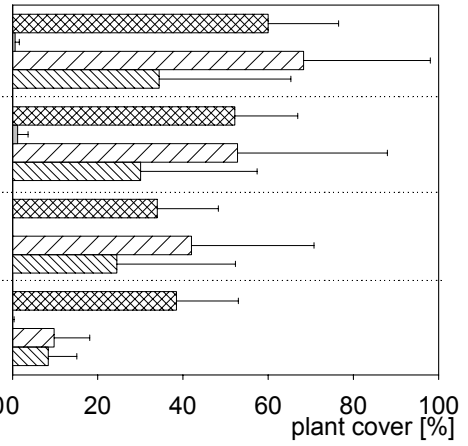

In the spruce forest the difference between the stand and the wheel tracks is not as big as those of the Solling beech forest; the reduction constitutes 54\%. More than a quarter of the nitrogen is mineralised in the thick humus layer (Fig. 2 and Tab. II). In the stand only $48 \mathrm{~kg} \mathrm{~N} \mathrm{ha}^{-1}$ is mineralised of which $44 \%$ is nitrate. $23 \mathrm{~kg} \mathrm{~N} \mathrm{ha}^{-1}$ is found along the wheel tracks, having a nitrification rate of $55 \%$.

\subsection{Species diversity, phytosociological behaviour and site ecology}

The total number of herb layer species in the different stands of beech and spruce is considerably lower than along the skidding tracks (Fig. 3). The beech forest on limestone has a total of 57 herbaceous species, a higher species richness than that of the beech and spruce forests of the Solling uplands (37 and 33 herbaceous species). In the three different stand types most plant species are found along the side-strips (59-76 herbaceous species) and even in the wheel tracks a large number of species occur. However, the herbaceous plants along the wheel tracks have a markedly lower cover (Fig. 4). Along the mid-line the total numbers of species are a little smaller than in the wheel tracks. Along the mid-line the plant cover in the beech forests is reduced compared with the undisturbed stands. The mean numbers of species (Fig. 3) show significant differences between the species richness in the stands compared with the skidding tracks in the beech forests. In the spruce forest, however, species richness along the skidding tracks only shows a slight increase.

Phytosociological spectra according to Ellenberg et al. [21] (Fig. 5) show that in the stands of the Göttingen forest most
Figure 4. Average plant cover [\%] with standard deviation of tree, shrub, herb and moss layer in the three forest types, divided into forest stands, side strips, mid-lines and wheel tracks. $n$ see Table I. 


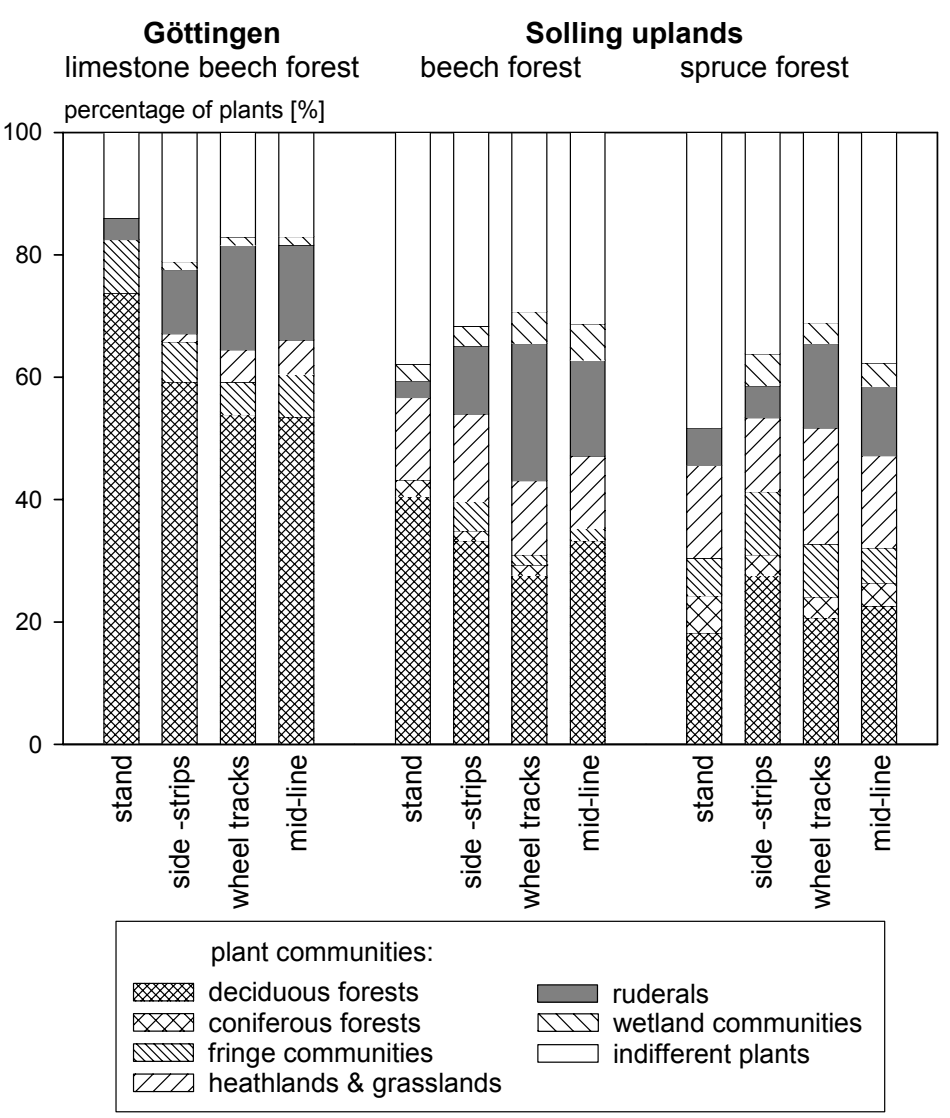

Figure 5. Spectra of the plant communities formed by Ellenberg et al. [21]. Shown are the three different stand types. Each spectrum is calculated for all plants occurring in the forest stands, along side-strips, wheel tracks and mid-lines, respectively. species belong to plant communities of deciduous forests, some originate from fringe communities and very few are ruderals. Along the skidding tracks the percentage of deciduous forest plant species decreases whereas ruderals as well as plants from grasslands increase, e.g. species like Alliaria petiolata, Geranium robertianum, Plantago major and Prunella vulgaris. In the beech forest of the Solling uplands the percentage of forest plant species is a little smaller and even in the stand $14 \%$ of the plant species belong to plant communities of the open landscape (Carex pilulifera, Juncus effusus). Again along the skidding tracks the percentage of ruderals (Stellaria media, Persicaria minor, Rumex obtusifolius) and of wet sites (Stellaria alsine) increase.

In the spruce forest stand phytosociological behaviour is more mixed. $31 \%$ of the herbaceous species are closely related to the forest communities, numerous plant species like Galium saxatile and Carex pilulifera are related to heathlands and grasslands, to clear cuttings (Epilobium angustifolium, Digitalis purpurea) and ruderal communities (Urtica dioica, Mycelis muralis). Along the side-strips the percentage of deciduous forest species (Festuca gigantea, Impatiens noli-tangere) and fringe communities increase while wheel tracks and mid-line were characterised by increasing numbers of ruderals. Plant species of wetland communities occur along the skidding tracks only.

Site factors are characterised by Ellenberg's indicator values [21] (Tab. III). The average light values of the herb layer indicate much higher light intensities in the spruce forest than in the beech stands where shade plants are quite frequent. In general, the tree layer is lower along the skidding tracks than in the adjacent stands independent of the tree species (Fig. 4). In the beech forests this effects a slight increase of light demanding plants and therefore in the mean light indicator values (Tab. III).

Table III. Arithmetic mean indicator values [21] for light, soil reaction and nitrogen figures. Given are the three forest types divided into stand, side strips, wheel tracks and mid-line. $n$ see Table I.

\begin{tabular}{lccc}
\hline Göttingen, beech forest & Light & Reaction & Nitrogen \\
\hline Stand & 3.5 & 6.8 & 6.1 \\
Side-strips & 3.8 & 6.8 & 6.2 \\
Wheel tracks & 4.3 & 6.7 & 6.3 \\
Mid-line & 3.9 & 6.8 & 6.3 \\
\hline Solling, beech forest & & & \\
\hline Stand & 4.1 & 3.8 & 4.9 \\
Side-strips & 4.8 & 4.2 & 5.2 \\
Wheel tracks & 5.0 & 5.3 & 6.3 \\
Mid-line & 5.0 & 5.2 & 6.3 \\
\hline Solling, spruce forest & & & \\
\hline Stand & 5.2 & 3.2 & 4.1 \\
Side-strips & 5.2 & 3.4 & 4.4 \\
Wheel tracks & 5.2 & 3.8 & 4.7 \\
Mid-line & 5.2 & 3.7 & 4.5 \\
\hline
\end{tabular}


As expected, in the beech forest on limestone, indicator plants of weak acid to weak basic conditions dominate. No changes along the skidding tracks are visible. In contrast, the Solling stands are characterised by plant species mainly found on acid soils. Besides, acidity indicators are more common in the spruce stands than in the close-to-nature beech stands. In both Solling sites the mean soil reaction indicator values are higher along the skidding tracks than in the undisturbed forest stands. These results apply also for the mean nitrogen indicator values with increasing figures from the side-strips to the wheel tracks and mid-line area. However, the differences between the three sites are not as clear as those regarding the soil reaction indicator values. In the Göttingen forest, plants often found in places rich in available nitrogen indicate better nutrient supply than in the sites of the Solling uplands where indicator plants of intermediate nitrogen availability dominate.

\section{DISCUSSION}

Net nitrogen mineralization in beech forests on limestone is assumed to be higher than in beech forests on acid soils [19]. However, Leuschner [41] and Schmidt [56] found that the net nitrogen mineralization in beech forests is not very variable between nutrient poor and nutrient rich forest soils. Sometimes it can be lower in a Hordelymo-Fagetum lathyretosum than in a Luzulo-Fagetum. The nitrogen mineralization activity [ppm $\mathrm{N}_{\min } 30$ weeks ${ }^{-1}$ ] in the Göttingen forest was nearly as high as in the Solling beech forest, but the lower bulk density and the shallow soils caused low amounts of net nitrogen mineralization according to the area $\left[\mathrm{kg} \mathrm{N}_{\min } \mathrm{ha}^{-1}\right]$. Schnieder [59] also measured a low nitrogen mineralization of $64 \mathrm{~kg} \mathrm{~N}$ $\mathrm{ha}^{-1} \mathrm{yr}^{-1}$ in the Göttingen forest while according to Schmidt [56] net nitrogen mineralization of the Hordelymo-Fagetum lathyretosum varied between 100 and $150 \mathrm{~kg} \mathrm{~N} \mathrm{ha}^{-1} \mathrm{yr}^{-1}$ and did clearly correlate with the degree of disturbance. In coniferous forests the mineralization is mostly lower than in deciduous forests $[2,39,65,66]$, which is also true in the Solling stands. However, this is not only an effect of the change in vegetation composition [4] but also dependent on the site factors. Moreover, the nitrogen mineralization activity is changing on small scale [65], so generalisations have to be taken with care. The spruce stand was found to be a little lower in $\mathrm{pH}$ values and richer in stone content than the beech forest on the Solling site. In long terms, nitrogen cycling of forest communities is well balanced $[1,19]$. Therefore net nitrogen mineralization measured in the undisturbed stands can be used as a reference for comparison with skidding tracks.

Along the wheel tracks the net nitrogen mineralization, especially the ppm values, are much lower than in the stands at all three sites. Soil compaction due to travelling of heavy machinery restricts soil aeration $[48,49,61]$ so that the activity of mineralization by soil microorganisms is inhibited. On the other hand, Gerlach [27] found on experimentally disturbed soil samples higher rates of nitrogen mineralization than in undisturbed samples, because of better soil aeration. Low mineralization rates can be induced by the disturbance of the humus layer. By harvesting traffic the litter layer is compacted and mixed with the surface mineral soil, or it is even missing in the beech forests. This again may cause lower aeration. In the spruce forest the inhibition of nitrogen mineralization along wheel tracks is not as distinctive. The forest floor is probably much better protected by branch mats which are often used in coniferous forests as a buffer between harvesters and soil surface. These branches protect the soil against deformation and soil compaction, if the layer is over $25 \mathrm{~cm}$ thick [12, 26, 50, 51]. Also the higher stone content may protect against soil deformation. Therefore, the mineral soil under the wheel tracks of the spruce site is not as compacted as the beech sites. This is indicated by a lower bulk density and increasing nitrification rate, whereas poor aeration would inhibit nitrification $[19,35]$. The slight increase of soil $\mathrm{pH}$ measured in the humus layer and the decrease of plant species mainly found on acid soils support this explanation. At all sites investigated, the nitrogen supply offered to plants has been reduced along the wheel tracks and might become a limiting factor in plant nutrition.

Contrasting to this the mean nitrogen indicator values increase from the forest stands towards the skidding tracks. This might be explained by the better light conditions in the beech forests (see below), as light-demanding species can be nitrogen indicators at the same time [21]. Schaffers and Sykora [52] found that "the N-values appeared to be only weakly correlated with soil parameters including N-mineralization and available mineral N" (p. 225), but were strongly correlated with biomass production. Furthermore, many of the plant species often found in places rich in available nitrogen are mainly ruderals or indicators of disturbance [32, 60]. Apart from this, along the skidding tracks, soil conditions have been so severely changed, that Ellenberg's indicator values should be viewed with caution [37]. Especially the nitrogen figures of the plant species recorded do not correlate with low net nitrogen mineralization measured in the wheel tracks. Instead they reflect the change in vegetation composition between the undisturbed stands and skidding tracks.

The mean indicator values calculated in the forest stands for light, soil reaction and nitrogen are more reliable. These reveal the different site conditions which also have different plant species richness $[14,20,41,55,58]$. Beech forests on limestone have a higher plant diversity than beech forests on acidic soils [14]. Instead of the close-to-nature beech forest, the planted spruce stands of the Solling uplands contain on average more plant species than the Luzulo-Fagetum. Increasing species diversity of the spruce stands (Galio harcynici-CultoPiceetum) is related to an increase of plant species originating from natural spruce forests, clear cuttings, grasslands and ruderal communities while typical plant species of the LuzuloFagetum still remain [58, 67].

Along the skidding tracks species richness is higher than in the undisturbed forest stands, although the plot size is smaller (cf. Chap. 2.2). This is effected by numerous species of nonforest communities, similar to the effect of substituting the close-to-nature beech forest by spruce plantation [58, 65, 67]. Some of these species (e.g. Prunella vulgaris, Ranunculus repens, Plantago major) are more resistant to mechanical stress or destruction than many forest plants [20,60]. Most of the non-forest plant species (e.g. Juncus spec., Роа апnиа, Prunella vulgaris) produce a permanent seed bank, are winddispersed, but also used forest harvesting machines for dispersal $[24,54]$. Some are only able to germinate in bare mineral soil as created along wheel tracks $[8,12,24]$. Some may benefit 
from the better light conditions caused by the opening of the beech canopies along the skidding tracks [20, 24, 57, 58]. In spruce stands, however, the thinning of the canopy along skidding tracks seemed to be of small importance. Light intensity in mature spruce stands is already much higher than in closed beech stands $[42,65]$.

The results are in agreement with other comparative investigations between almost unmanaged and managed forests. In managed forests, harvesting as well as soil disturbance and compaction due to heavy machinery increase species diversity [8, 9, 12, 30, 55]. Schall [53], Glowienka [29] and Mrotzek et al. [45] compared the vegetation along forest roads with the adjacent stands. They found high species numbers along the forest roads, caused by different site conditions and disturbance effects.

Increasing species diversity of herbaceous plants increases the food and habitat resources for many animal species such as insects, e.g. butterflies [18], birds and deer [53]. However, the increase in species diversity is clearly related to a decrease of naturalness. In general, plant species colonising the skidding tracks are not rare, e.g. on lists of endangered species, but they are common in open habitats and rare in unmanaged or virgin forests [55].

Skidding tracks are a result of human interference and cause disturbances within forest ecosystems which influence the properties of soils and therefore indirectly have an impact on the vegetation. Close-to-nature forests like beech forests are one of the most natural vegetation types found in Central Europe [20]. Therefore it can be concluded, to minimise the invasion of non-forest species in these forests and to reduce soil compaction, harvesting traffic should be restricted to a few permanent skidding tracks.

Acknowledgements: The study received financial support from the German Research Society (DFG). Thanks to A. Bauer, A. Parth and $\mathrm{H}$. Rubbert for their help during fieldwork and in the laboratory. We are grateful to C. Guest and T. Harres for their language corrections.

\section{REFERENCES}

[1] Aber J.D., Melillo J.M., McClaugherty C.A., Echleman K.N., Potential sinks for mineralized nitrogen following disturbance in forest ecosystems, Ecol. Bull. 35 (1983) 179-192.

[2] Aber J.D., Melillo J.M., Nadelhoffer K.J., McClaugherty C.A., Pastor J., Fine root turnover in forest ecosystems in relation to quantity and form of nitrogen availability: a comparison of two methods, Oecologia 66 (1985) 317-321.

[3] Ågren A., Produktionsverluste in Durchforstungsbeständen als Folge der modernen Rücketechnik, AFZ/Wald 39 (1969) 758.

[4] Augusto L., Ranger J., Binkley D., Rothe A., Impact of several common tree species of European temperate forests on soil fertility, Ann. For. Sci. 59 (2002) 233-253.

[5] Becker G., Die Entwicklung der Forsttechnik - aus der Sicht der Walderschließung, AFZ/Wald 16/17 (1985) 398-399.

[6] Behrndt W., Stand und Entwicklung der Mechanisierung in der Holzernte als Beitrag zur Effizienzsteigerung des Staatsforstbetriebes Niedersachsen, Forst Holz 53 (1998) 363-372.

[7] Benecke P., Auswirkung des Befahrens mit schweren Fahrzeugen auf bodenphysikalische Kennwerte (Kurzfassung), Mitt. Dtsch. Bodenkdl. Ges. 34 (1982) 181-186.
[8] Brunet J., Falkengren-Grerup U., Tyler G., Herb layer vegetation of south Swedish beech and oak forests - effects of management and soil acidity during one decade, For. Ecol. Manage. 88 (1996) 259272

[9] Brunet J., Falkengren-Grerup U., Rühling A., Tyler G., Regional differences in floristic change in South Swedish oak forests as related to soil chemistry and land use, J. Veg. Sci. 8 (1997) 329336

[10] Bücking W., Nitrifikation als Standortfaktor von Waldgesellschaften, Diss., Univ. Freiburg i. B., 1970.

[11] Deconchat M., Effets des techniques d'exploitation forestière sur l'état de surface du sol, Ann. For. Sci. 58 (2001) 653-661.

[12] Deconchat M., Balent G., Effets des perturbations du sol et de la mise en lumière occasionnées par l'exploitation forestière sur la flore à une échelle fin, Ann. For. Sci. 58 (2001) 315-328.

[13] Denninger W., Stand der mechanisierten Holzernte in Niedersachsen, Holz-Zent.bl. 77 (2002) 947.

[14] Dierschke H., Pflanzensoziologische und ökologische Untersuchungen in Wäldern Süd-Niedersachsens. II. Syntaxonomische Übersicht der Laubwald-Gesellschaften und Gliederung der Buchenwälder, Tuexenia 5 (1985) 491-521.

[15] Dierschke H., Artenreiche Buchenwald-Gesellschaften NordwestDeutschlands, Ber. d. Reinh. Tüxen-Ges. 1 (1989) 107-148.

[16] Dierschke H., Pflanzensoziologie, Ulmer, Stuttgart, 1994.

[17] Dietz P., Knigge W., Löffler H., Walderschließung, Parey, Hamburg, Berlin, 1984.

[18] Dover J., Sparks T., Gobbett K., Glossop S., Linear features and butterflies: the importance of green lanes, Agric. Ecosyst. Environ. 80 (2000) 227-242.

[19] Ellenberg H., Stickstoff als Standortsfaktor, insbesondere für mitteleuropäische Pflanzengesellschaften, Oecol. Plant. 12 (1977) $1-22$.

[20] Ellenberg H., Vegetation Mitteleuropas mit den Alpen, 5th ed., Ulmer, Stuttgart, 1996.

[21] Ellenberg H., Weber H.E., Düll R., Wirth V., Werner W., Paulißen D., Zeigerwerte von Pflanzen in Mitteleuropa, Scr. Geobot. 18 (1992) $258 \mathrm{p}$.

[22] Eno C.F., Nitrate production in the field by incubating the soil in polyethylene bags, Soil Sci. Soc. Am. Proc. 24 (1960) 277-279.

[23] Firbas F., Spät- und nacheiszeitliche Waldgeschichte Mitteleuropas nördlich der Alpen, 2nd Vol., Waldgeschichte der einzelnen Landschaften, Fischer, Jena, 1952.

[24] Fischer A., Untersuchungen zur Populationsdynamik am Beginn von Sekundärsukzessionen, Diss. Bot. 110 (1987) 234 p.

[25] Forbrig A., Rückegassenabstände - ein heißes Eisen, Forsttech. Inf 6 (1994) 57-59.

[26] Fries J., Ökologische Aspekte der mechanisierten Durchforstung, Forst Holz 17 (1975) 315-320.

[27] Gerlach A., Methodische Untersuchungen zur Bestimmung der Stickstoffnettomineralisation, Scr. Geobot. 5 (1973) 1-115.

[28] Gerlach A., Krause A., Meisel K., Speidel B., Trautmann W., Vegetationsuntersuchungen im Solling, Schr.reihe Veg.kd. 5 (1970) $75-134$.

[29] Glowienka M., Waldwege im Harz und ihre Standortfaktoren, Dipl. Arb., Univ. Göttingen, 1994.

[30] Gondart H., Deconchat M., Effects of soil surface disturbances after logging on plant functional types, Ann. For. Sci. 60 (2003) 725-732.

[31] Grime J.P., Benefits of plant diversity to ecosystems: immediate, filter and founder effects, J. Ecol. 86 (1998) 902-910.

[32] Grime J.P., Plant strategies, vegetation processes, and ecosystem properties, Wiley, Chichester, 2001.

[33] Guglhör W., Akzeptanzprobleme beim Einsatz von Kranvollerntern in der Durchforstung, AFZ/Wald 17 (1993) 892-895. 
[34] Hofmann R., Bodenschäden durch Forstmaschineneinsatz Untersucht am Beispiel lehmig-sandiger Böden auf Buntsandstein bei Befahrung im Zustand der Frühjahrsfeuchte, Diss., Univ. Freiburg i. Br., 1989

[35] Janiesch P., Mellin C., Müller E., Die Stickstoff-Netto-Mineralisation in naturnahen und degenerierten Erlenbruchwäldern als Kenngröße zur Beurteilung des ökologischen Zustandes, Verh. Ges. Ökol. 20 (1991) 353-359.

[36] Kewton A., Zucker A., Bodenverdichtung in Waldböden: Versuch eines Bewertungsrasters der Verdichtungsempfindlichkeit, AFZ/ Wald 15 (1993) 772-777.

[37] Kowarik I., Seidling W., Zeigerwertberechnungen nach ELLENBERG - Zu Problemen und Einschränkungen einer sinnvollen Methode, Landschaft und Stadt 21 (1989) 132-143.

[38] Kremser W., Otto H.-J., Grundlagen für die langfristige, regionale waldbauliche Planung in den niedersächsischen Landesforsten, Mitteilungen aus der Niedersächsischen Landesforstverwaltung, Aus dem Walde 20 (1973) $496 \mathrm{p}$.

[39] Kriebitzsch W.-U., Bühmann H., Stickstoff-Mineralisation im Boden eines Eichen-Buchen-Waldes und eines Kiefernforstes in der nordwestdeutschen Tiefebene, Forstw. Cbl. 108 (1989) 255270 .

[40] Leuschner C., Das Konzept der potentiellen natürlichen Vegetation (PNV): Schwachstellen und Entwicklungsperspektiven, Flora 192 (1997) 379-391.

[41] Leuschner C., Zur Abhängigkeit der Baum- und Krautschicht mitteleuropäischer Waldgesellschaften von der Nährstoffversorgung des Bodens, Ber. d. Reinh.-Tüxen-Ges. 11 (1999) 109-131.

[42] Lücke K., Schmidt W., Vegetation und Standortsverhältnisse in Buchen-Fichten-Mischbeständen des Sollings, Forstarchiv 68 (1997) 135-143.

[43] Nadelhoffer K.J., Aber J.D., Melillo J.M., Seasonal patterns of ammonium and nitrate uptake in nine temperate forest ecosystems, Plant Soil 80 (1984) 321-335.

[44] Mrotzek R., Wuchsdynamik und Mineralstoffhaushalt der Krautschicht in einem Buchenwald auf Basalt, Ber. Forsch.zentr. Waldökosyst. A 152 (1998) 197 p.

[45] Mrotzek R., Pfirrmann H., Barge U., Einfluss von Wegebaumaterial und Licht auf die Vegetation an Waldwegen und im angrenzenden Bestand - dargestellt an Wegen im Niedersächsischen Forstamt Bramwald, Forstarchiv 71 (2000) 234-244.

[46] Niedersächsisches Ministerium für Ernährung, Landwirtschaft und Forsten, Waldentwicklung Solling, Fachgutachten, Waldentwicklung in Niedersachsen 5 (1996) 149 p.

[47] Rehfuess K.E., Waldböden. Entwicklung, Eigenschaften und Nutzung, 2nd ed., Parey, Hamburg, Berlin, 1990.

[48] Runge M., Untersuchungen über die Mineralstickstoff-Nachlieferung an nordwestdeutschen Waldstandorten, Flora 155 (1965) 353 386.

[49] Schack-Kirchner H., Struktur und Gashaushalt von Waldböden, Ber. Forsch.zent. Waldökosyst. A 112 (1994) 145 p.

[50] Schäfer T., Sohns D., Minderung der Bodenverdichtung durch eine Reisigauflage, AFZ/Wald 9 (1993) 452-455.

[51] Schäffer J., Hildebrand E.E., Mahler G., Wirkung der Armierung durch Reisigmatten. Bodenverformung beim Befahren, AFZ/Wald 11 (1991) 550-554.
[52] Schaffers A.P., Sykora K.V., Reliability of Ellenberg indicator values for moisture, nitrogen and soil reaction: a comparison with field measurements, J. Veg. Sci. 11 (2000) 225-244.

[53] Schall B., Die Vegetation der Waldwege und ihre Korrelation zu den Waldgesellschaften in verschiedenen Landschaften Süddeutschlands mit einigen Vorschlägen zur Anlage und Pflege von Waldwegen, Ber. Akad. Nat.schutz Landsch. Pfl. 12 (1988) 105-140.

[54] Schmidt W., Plant dispersal by motor cars, Vegetatio 80 (1989) $147-152$.

[55] Schmidt W., Die Bodenvegetation als Indikator für die biotische Mannigfaltigkeit von Wäldern - Beispiele aus Naturwaldreservaten und Wirtschaftswäldern, Verh. Ges. Ökol. 29 (1999) 133-143.

[56] Schmidt W., Stickstoffkreislauf in Schlaglücken eines Kalkbuchenwaldes, AFZ/Wald 173 (2002) 67-76.

[57] Schmidt W., Weitemeier M., Holzapfel C., Vegetation dynamics in canopy gaps of a beech forest on limestone - Influence of the light gradient on species richness, Verh. Ges. Ökol. 25 (1996) 253-260.

[58] Schmidt W., Weckesser M., Struktur und Diversität der Waldvegetation als Indikatoren für eine nachhaltige Waldnutzung, Forst Holz 56 (2001) 493-498

[59] Schnieder B., Vergleichende bodenökologische Untersuchung zweier Auflichtungen im Kalkbuchenwald, Dipl. Arb., Univ. Göttingen, 1992.

[60] Seibert P., Die Belastung der Pflanzendecke durch den Erholungsverkehr, Forstw. Cbl. 93 (1974) 35-43.

[61] Startsev A.D., McNaab D.H., Skidder traffic effects on water retention, pore-size distribution, and van Genuchten parameters of Boreal forest soils, Soil Sci. Soc. Am. J. 65 (2001) 224-231.

[62] Suwala M., Einfluß verschiedener Erntevarianten auf Baum- und Bodenschäden bei der Durchforstung in Kiefernbeständen. Vergleich und Bewertung der Bestandes-, Boden- und Wurzelschäden von fünf in Polen gebräuchlichen Holzernteverfahren, Forsttech. Inf. 9 (1997) 114-117.

[63] Tüxen R., Die heutige potentielle Vegetation als Gegenstand der Vegetationskartierung, Angew. Pflanzensoziol. 13 (1956) 5-42.

[64] Wagenhoff A., Der Wald in der Bovender Flur und der heutige Wald der Realgemeinde Bovenden, Plesse-Archiv 26 (1990) 121150 .

[65] Weckesser M., Die Bodenvegetation von Buchen-FichtenMischbeständen im Solling - Struktur, Diversität und Stoffhaushalt, Diss., Univ. Göttingen, Cuvilier, 2003.

[66] Wölfelschneider A., Einflußgrößen der Stickstoff- und SchwefelMineralisierung auf unterschiedlich behandelten Fichtenstandorten im Südschwarzwald, Freibg. bodenkd. Abh. 34 (1994) 191 p.

[67] Zerbe S., Fichtenforste als Ersatzgesellschaften von HainsimsenBuchenwäldern, Vegetation, Struktur und Vegetationsveränderungen eines Forstökosystems, Ber. Forsch.zent. Waldökosyst. A 100 (1993) $173 \mathrm{p}$.

[68] Zerbe S., Meiwes K.J., Zum Einfluß von Weichlaubhölzern auf Vegetation und Auflagehumus von Fichtenforsten - Untersuchungen in einem zwei Jahrzehnte alten Birken-Ebereschen-Vorwald im Hoch-Solling, Forstw. Cbl. 119 (2000) 1-19.

[69] Zöttl H., Methodische Untersuchungen zur Bestimmung der Mineralstickstoffnachlieferung des Waldbodens, Forstw. Cbl. 79 (1960) 72-90. 